\title{
Correction: Healthy dietary indices and risk of depressive outcomes: a systematic review and meta-analysis of observational studies
}

\author{
Camille Lassale - G. David Batty • Amaria Baghdadli • Felice Jacka (1) - Almudena Sánchez-Villegas • \\ Mika Kivimäki 1 - Tasnime Akbaraly $\mathbb{B}$
}

Published online: 4 March 2021

(c) The Author(s) 2021. This article is published with open access

Correction to: Molecular Psychiatry

https://doi.org/10.1038/s41380-018-0237-8

Following publication of this article, CL contacted the journal to request the addition of the following text to the 'Conflict of Interest' declaration: 'FJ has received: (1) competitive Grant/Research support from the Brain and Behaviour Research Institute, the National Health and Medical Research Council (NHMRC), Australian Rotary Health, the Geelong Medical Research Foundation, the Ian Potter Foundation, The University of Melbourne; (2) industry support for research from Meat and Livestock Australia, Woolworths Limited, the A2 Milk Company, Be Fit Foods; (3) philanthropic support from the Fernwood Foundation, Wilson Foundation, the JTM Foundation, the Serp Hills Foundation, the Roberts Family Foundation, the Waterloo Foundation and; (4) travel support and speakers honoraria from Sanofi-Synthelabo, Janssen Cilag, Servier, Pfizer, Network Nutrition, Angelini Farmaceutica, Eli Lilly and Metagenics. FJ has written two books for commercial publication.' All other authors declare that they have no conflict of interest. This has now been corrected in both the PDF and HTML versions of this article.

Open Access This article is licensed under a Creative Commons Attribution 4.0 International License, which permits use, sharing, adaptation, distribution and reproduction in any medium or format, as long as you give appropriate credit to the original author(s) and the source, provide a link to the Creative Commons license, and indicate if changes were made. The images or other third party material in this article are included in the article's Creative Commons license, unless indicated otherwise in a credit line to the material. If material is not included in the article's Creative Commons license and your intended use is not permitted by statutory regulation or exceeds the permitted use, you will need to obtain permission directly from the copyright holder. To view a copy of this license, visit http://creativecommons. org/licenses/by/4.0/. 